\title{
【論文】
}

\section{デポジット制度を伴うリサイクル制度において 消費者の知識が製品属性評価に与える影響}

\author{
—テレビについてのケーススタディ—
}

増田明之**松本凱斗* . 村上進 亮*

【要 旨】消費者の制度理解の向上のみに依存して適正廃棄行動を促進することには限界がある。たと えば 2001 年から施行されている家電リサイクル法では, 使用済み製品の回収率向上は依然として課題 である。使用済み製品の回収促進策としてはデポジット制度の導入も考えられるが，預り金の支払いに よる製品需要の低下も懸念される。そこで本論は家電リサイクル制度に㧍けるデポジット制度を例にと り，制度に関する情報提示とコストの負担感の軽減の関係について分析した。本論では現行の家電リサ イクル法に扔けるデポジット制度の概形を提示し，行為目標の同定の観点から消費者の製品属性に対す る評価への介入モデルの設計を行った。負担感の推定にはコンジョイント分析を用い, テレビを例とし てモデルの有効性を検証した。分析結果から預り金の支払いは消費者にとって負担として認識されてい ること，また同定の操作は負担感の軽減に有効であることが示唆された。

キーワード：リサイクル, デポジット, 購買行動, コンジョイント分析

\section{1. 研究背景と目的}

わが国は循環型社会形成推進基本法の下，さまざまな 個別リサイクル法を整備し, 循環型社会への移行を進め てきたところではあるが，特に耐久消費財を対象とする ようなリサイクル制度にとって, 回収率の向上は依然と して課題である。たとえば特定家庭用機器再商品化法 (家電リサイクル法) に基づくリサイクル制度 (以降, 家 電リサイクル制度)では不法投棄等の「見えないフロー」 の抑制を図ることが課題とされ，消費者等の排出者から 制度内の適正ルートへの使用済み製品の回収率向上が求 められている。2014年に行われた家電リサイクル制度 の施行状況の評価・検討では, 消費者行動の観点での改 善点に触れており, 家電リサイクル制度についての理解 の促進やリサイクル料金の低減の検討が指摘されてい る1)。

原稿受付 2019.1.15＼cjkstart原稿受理 2019.9.16

* 東京大学大学院 工学系研究科 システム創成学専攻 連絡先 : ₹ 113-8656 東京都文京区本郷 7-3-1

東京大学大学院 工学系研究科 システム創成学尃攻 村上 進亮 E-mail:smurakam@sys.t.u-tokyo.ac.jp
実際に過去の事例からリサイクル料金の軽減は回収率 の向上に有効であると考えられる。2008 年から 2010 年 にかけて行われた家電エコポイント制度は，実質的に家 電リサイクル制度にのっとった廃棄行動（適正廃棄行 動) への経済的インセンティブとして機能し, 回収対象 の家電 4 品目 (対象品目) すべてにおいて排出台数べー スでの回収率が向上した(たとえば液晶・プラズマ式テ レビでは 2009 年度の回収率の推計值は $31 \%$ であった

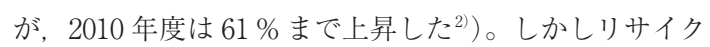
ル料金の割引による施策には大きな費用がかかり，回収 率向上のためだけにリサイクル料金の割引を行うことは 現在の排出者による費用負担の枠組みとも整合しない。 結局のところ, 現在全国的に行われている適正廃棄行動 の促進施策は, 制度理解についての広報活動 ${ }^{3,4)}$ のみで ある。

リサイクル料金の排出者負担を維持しながら適正廃書 行動に経済的インセンティブを付与するための施策とし ては，消費者から製品購入時に預り金を徴収し，使用済 み製品の引き渡しと引き換えに預り金の一部または全額 を返却するデポジット制度が考えられる。デポジット制 度は日本国外を中心に飲料容器を対象とした導入実績が 
多数ある。家電製品については極めて少数ながら存在す るとされるが5)，導入後の評価については報告されてお らず, 前例がないに等しいといえる。

飲料容器の事例では預り金の徴収が製品需要に負の影 響を与えることが指摘されている ${ }^{6)}$ 。家電リサイクル制 度の対象品目においても同様の影響が予想される。対象 品目の重量やサイズは飲料容器よりもはるかに大きく, 引き渡しにかかる負担も大きいため, 適正廃棄への有効 なインセンティブを確保するためには預り金も高く設定 する必要がある。さらに対象品目における製品需要は主 に買い換えに起因すると考えられるが, この場合, デポ ジット制度開始後に最初に支払う預り金はこの制度下で 買い換えを続ける限り預けたままになる。つまり家電の 場合, 預り金と払い戻し金が同額であったとしても, 預 り金の徵収は多くの消費者にとって実質的に一時的なコ ス卜負担の増加となり, 結果的に需要の減少を招くこと になると考えられる。よってリサイクル料金やデポジッ 卜制度の預り金等の資源循環にかかる費用を排出者(消 費者)が負担するとき，その負担感を軽減させることは 適正廃棄行動を促進する上で重要な課題であるといえる。 以上の論点を踏まえ, 本論では家電リサイクル制度に おけるデポジット制度を例にとり, 制度についての情報 提示によって支払いに対する負担感を軽減することにつ いての有効性を分析する。本論では消費者行動研究の知 見をもとにメッセージの内容を設計し, コンジョイント 分析を用いてデポジット制度の導入による負担感ならび に製品需要と関連する購入確率の低下を軽減する方策に ついて検討する。

国内外を問わず，明示的にリサイクル料金を徴収する 制度とデポジット制度が併存する事例は少ない。そこで 実務的な示唆を明確にするため, 続く2.では本論で想 定する家電リサイクル制度におけるデポジット制度の概 観を提示する。この想定と既往の消費者行動研究の知見 を踏まえ， 3. 以降で預り金徵収による効用減少を緩和す る説得的コミュニケーションのモデルを考える。

\section{2. 想定するデポジット制度の概観}

\section{1 リサイクル費用の支払い方式とデポジット制度}

家電リサイクル法の特徵は排出者にも費用負担を義務 づけていることである。各国の拡大生産者責任に基づく リサイクル制度では，一般に製造者が費用支払いを含め たリサイクルの責任をもつこととされ，実質的にはリサ イクル料金は製品価格に転嫁されている。一方で家電リ サイクル法は製造者だけでなく製品のユーザーである消 費者にも排出者としての責任分担を求めており, さらに
リサイクル料金は製品の廃棄時に徴収される（いわゆる 後払い方式)。後払い方式は不適正な廃棄の一因として しばしば問題視されており ${ }^{7}$, 前払い方式への移行も常 に論点の一つである ${ }^{89}$ 。

家電リサイクル法の制定に先立ち産業構造審議会では, 費用の回収方法については前払い（将来充当, 当期充 当), 後払い, 強制デポジット制度, 新税の導入, の 5 つの案が検討された ${ }^{10)}$ 。将来充当と当期充当の区分は支 払者と排出者の一致, 不一致に対応する。すでに保有さ れている製品からも対象にすることができること, 製品 寿命が長いことから排出時の技術水準を踏まえた料金を 設定するほうが公正であること, 排出抑止の効果 (使用 年数の長期化) も期待されることなどの利点が重視され, 後払いを支持する意見が相対的に多かったとされる ${ }^{10)}$ 。 ただし田崎らは家電リサイクル制度の導入後の使用年数 の長期化への効果は限定的であったとしている7

2008 年と 2014 年の家電リサイクル制度見直しの議論 では前払い方式への移行が検討されたが, 現在まで後払 い方式が維持されて続けている。この背景として前払い 方式によって製品需要が低下した場合，実質的に製造者 の負担が増大することへの懸念 ${ }^{10)}$ があげられる。貫と遠 山は前払い方式の導入に家電産業が消極的であったとし， その理由として価格に対するリサイクル料金の割高感が 大きい, より競争的である家電市場のほうが受けるダ メージが大きいことをあげている ${ }^{11)}$ 。家電リサイクルよ りも後に導入された自動車リサイクルでは前払い方式が 採用されたが, この理由として自動車の価格帯に対して リサイクル料金が低廉であることがあげられる。以上の 経緯を踏まえると, 家電リサイクルにおいて前払い方式 を導入する場合, 支払者と排出者が一致する将来充当方 式が妥当であると考えられる。しかしリサイクル費用は 技術水準, 再生材需給, 法制度, 社会情勢等, さまざま な要因により変動しうる。製品寿命が比較的長い家電製 品において, 購入時にリサイクル費用を算定することは 困難であると考えられる。デポジット制度も購入時に一 定の金額を徵収する点では前払い方式と同じであるが, 預り金とリサイクル費用とでは，前者のほうが金額設定 において考慮すべき因子は単純である。預り金は単なる 適正廃棄の経済的インセンティブの原資であり, 回収後 の処理方法等の技術にかかわる議論とは独立して設計す ることができる。

したがって, 将来充当方式を採用するよりも後払い方 式とデポジット制度を組み合わせるほうが所与の変化に 柔軟に対応することが可能であるという点で望ましいと 考えられる。デポジット制度と後払い方式とを組み合わ せる場合, ユーザーにとって払い戻し金からリサイクル 
料金を引いた額が正であるほうが直感的に受け入れやす いと考えられるが, この場合には預り金の金額設定にお いても所与の不確実性は問題となりうる。ただしこの問 題は預り金をリサイクル料金よりも十分に多く徴収する ことで対応可能である。

そこで本論では後払い方式の維持を前提にし, 技術水 準等による多少の変動を考慮し, 現行のリサイクル料金 よりも十分に大きい預り金を想定したデポジット制度の 導入について考える。本論ではデポジット制度を回収促 進の施策と位置づけ, 実務的な観点から家電エコポイン 卜制度のような期間を限定した導入も可能となるよう, 家電リサイクル制度とは会計上独立した制度を想定する。 この制度ではユーザーは製品購入時にリサイクル料金と 収集運搬費用の合計を十分に上回る預り金を支払い，使 用済み製品を適正廃棄することでこの預り金の払い戻し を受けることができるとする。またユーザーは適正廃棄 する際に現在の家電リサイクル制度と同一の手続きに よってリサイクル料金を支払うことを想定する。

\section{2 デポジット制度の管理運営費用}

次にデポジット制度の管理運営にかかる費用について 概観する。料金の徵収と返還を含むリサイクル制度の先 行事例としては使用済自動車の再資源化等に関する法律 （以下，自動車リサイクル法）を参考にすることができ る。自動車リサイクル法ではユーザーは自動車購入時に リサイクル料金を預託し中古車として輸出する場合には そのリサイクル料金が返還される。換言すれば自動車リ サイクル法では単にリサイクル費用の徴収だけでなく製 品個体ごとに払い戻しするためのシステムが整備されて いる。この法に拉けるリサイクル制度（自動車リサイク
ル制度）において，資金管理にかかる費用は自動車の製 造者・輸入者が固定費とランニングコストの一部を負担 し，ユーザーはリサイクル料金の一部として残りのラン ニングコストを負担している ${ }^{12)}$ 。自動車リサイクル制度 に扔ける 1 台あたりのユーザー負担分は 2017 年度まで は 380 円であった (2017 年度からは290円) ${ }^{13)}$ 。また払 い戻しについては, 自動車リサイクル制度では輸出の際 にリサイクル料金を取り戻す手数料として 210 円+消費 税が請求される（オンライン申請の場合, 2018 年度ま では 340 円 ${ }^{13)}$ 。よって実質的に資金管理分の料金は別 途徴収しているに等しい。

家電リサイクルにおいても同様にデポジット制度の資 金管理にかかる費用のうちユーザーが負担すべき分（管 理料金) を別途徴収することが想定される。本論ではデ ポジット制度における管理費用を明示的に徴収すること を想定する。家電リサイクルのデポジット制度で自動車 リサイクル制度と同様の資金管理スキームを想定した場 合, 家電 4 品目の年間出荷台数は自動車の年間出荷台数 に比べ約 4 倍多く ${ }^{14-16)}$, 手続き件数に関する規模の経済 により, 家電リサイクルの場合には自動車リサイクルの 場合よりも1台あたりの費用の低減が期待できる。

\section{3. 評価介入モデル}

本論では，（1）家電リサイクル制度に関する情報提示 (以降, 家電リサイクル制度の情報提示) によりリサイ クルという行為の目的についての認識を操作する, (2) その評価と関連する製品属性を明示することによって製 品購入の効用を向上させる, という 2 つのプロセスによ り, 預り金の徵収によって生じる効用の減少分を補償す

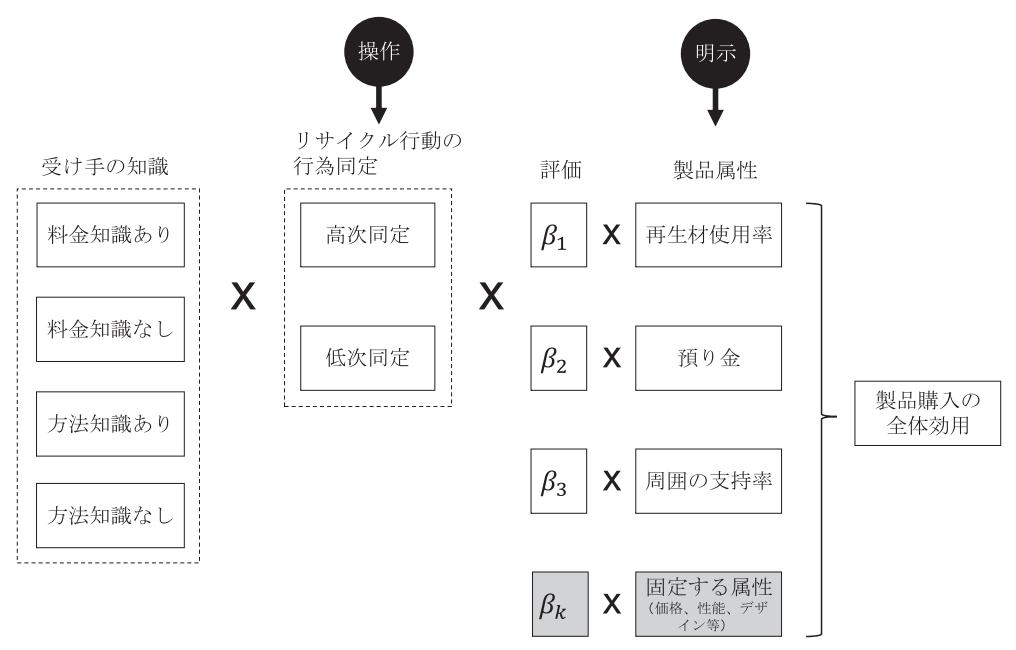

図 1 評価介入モデルと知識についてのセグメンテーション 
るモデル（以下，評価介入モデル）について検討する (図 1)。評価介入モデルでは価格やデザイン等の基本的 な属性変数の值を固定し, 情報提示に影響を受けると考 えられる属性変数についての評価 $\left(\beta_{1}, \beta_{2}, \beta_{3}\right.$, 後述) に介入する。既往の広報では, 一つの媒体に廃棄方法か ら不法投棄の問題までさまざまな内容が混在している事 例が多い ${ }^{3,4)}$ 。そこで本論では行為同定という概念 ${ }^{17-19)}$ か ら内容設計について整理し, 説得に効果的な内容につい て検討する。

\section{1 行為同定と説得}

リサイクル行動は環境配慮行動の下位概念として扱わ れることが多い。環境配慮行動を促進することを目的と した説得的コミュニケーションは社会的便益, 実行可能 性, 個人のベネフィットという 3 つの訴求タイプに分け ることができる20)。このうちリサイクル制度の目的の理 解を通じたリサイクル行動の促進は社会的便益の訴求に 分類される。

このように説得的コミュニケーションの機能的な特徵 に注目するとリサイクル行動は環境配慮行動の一種と捉 えられるが, 行為の目的に注目した場合にはリサイクル 行動は必ずしも環境配慮行動の下位概念とはならない。 一般に資源循環政策の目的は環境保護の他にも資源供給 など複数存在する。消費者にとっても, リサイクル行動 とは,リサイクルという目標でカテゴライズされたごみ の分別や適正廃棄や再生材使用製品の購入等, 具体的な 行為である。消費者がリサイクル行動を行うためには少 なくとも具体的な行為についてリサイクルという目標の カテゴリーを認知することが必要となる。消費者が家電 リサイクル制度のような資源循環政策に揭げられた目的 をもってリサイクル行動を行うということは, 消費者は リサイクルという目標カテゴリーを認知し, さらにその 目標の先にある政策的目標を認知していることを意味す る。したがって，具体的な行為にどのような目標を関連 づけるかは情報提示の内容設計の根本的な設計変数の一 つであるといえる。

目標が行為に及ぼす影響の心理学的枠組みは, 行為同

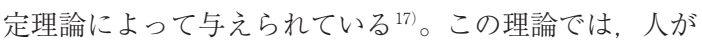
「どのように」行為を実行するかに注目している状態を 低次レベルで同定されていると呼び, 反対に「なぜ」そ の行為を実行するのかということに注目している状態を 高次レベルで同定されていると呼ぶ ${ }^{19)}$ 。高次で同定され ている行為は文脈の影響を受けにくく，自己概念との一

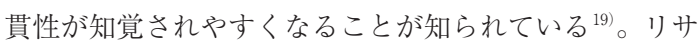
イクルにおいては, 消費者が使用済み製品の回収促進自 体に注目するとき低次レベル, リサイクルの結果として
もたらされる社会的便益に注目するとき高次レベルと捉 えることができる。評価介入モデルでは情報提示によっ て行為同定の操作を行う。高次と低次の同定を促す 2 つ の異なるメッセージを用意し，回答者によって提示する メッセージを変える。これら2つのメッセージをそれぞ れ提示する 2 群（高次同定群と低次同定群）に何も情報 提示をしない統制群を加え, これら 3 群について属性変 数に対する評価の違いを比較する。

\section{2 製品属性}

リサイクルに関する属性変数の評価は行為の同定から 影響を受けると想定される。再生材を使った製品を選ぶ など，ある特定の製品属性に注目して意思決定すること は一つの行為であるからである。消費者が適正廃棄行動 を制度上望ましい資源循環の一部と同定している場合, 適正廃棄とリサイクルに配慮した製品を選択することは 自己一貫的であると知覚しやすい。しかし単に使用済み 製品の回収促進として同定しているのであれば，適正廃 棄行動と再生材を使用した製品を選択することの間に関 連性を見出すことは難しい。高次レベルではその製品選 択が資源循環に貢献するかどうかに，低次レベルでは回 収に貢献するかどうかについての判断から属性が評価さ れると想定される。

具体的な製品属性としては, 前者は製品重量に占める 再生材の割合 (再生材使用率), 後者は預り金が考えら れる。実際のデポジット制度運営では同一の品目には同 一の預り金が設定されることが多いが，預り金支払い金 額と負担感の関係を推定するにあたっては異なる金額を 設定する必要がある。調査手続き的観点でも, 政策立案 の予備調査という文脈で同一の政策に対して異なる貨幣 属性変数を提示し, その政策に対する評価を推定するこ とは広く行われており調査の設定として妥当であるとい える。よって本論では預り金支払い金額を属性変数とし て扱うこととする。

評価介入モデルでは行為同定を操作し, この 2 つの属 性に対する評価に介入する。加えて, メッセージが行為 同定に与える影響を推察する手がかりとして, 考慮する 属性には製品に対する周囲の支持率も加える。低次で同 定されている場合, 周囲の支持といった文脈的な手がか りの影響を受けやすくなると想定されるからである。

\section{3 受け手の知識と説得}

説得的コミュニケーションにおいて, メッセージがど のように受容されるかは受け手側の心理的状態も影響さ れる。解釈レベル理論では, 行為同定理論と同様に認知 的階層を想定し, 行動や製品属性等の対象について, そ 
増 田明之・松

の心理的距離（感覚的な遠さ）が遠くなるほど解釈レベ ルが高くなる（解釈が抽象的になる）ことを示してい $ろ^{21)}$ 。高次の解釈は具体的な情報が不足する場合に行わ れる傾向にあるとされる。この理論によれば心理的距離 が遠い対象は意味的な思考 (なぜ) で捉えられ，心理的 距離が近い対象については手続き的な思考（どのよう に）で捉えられる。対象との心理的距離が近い場合, 抽 象的なメッセージよりも具体的なメッセージのほうが受 容されやすい傾向にある ${ }^{22)}$ 。既存の家電リサイクル制度 における広報は, 適正廃棄の手続きや「ルールを守ろ う」といった規範性等を強調し, リサイクル制度自体に 貢献すること, すなわち低次の目標で適正廃棄を行うこ とを促す内容である場合が多い ${ }^{3,4)}$ 。この点を踏まえる と, すでに家電リサイクル制度についての手続き的知識 を有する消費者は少なくとも回収促進という低次の目標 で同定された適正廃棄との心理的距離が近く,この知識 を有しない消費者に比べてこのような低次の行為目標に おいて具体性の高いメッセージを受容しやすいと想定さ れる。

評価介入モデルでは家電リサイクル制度の手続き的知 識の有無についても質問し，メッセージの受容のされ方 との関連を検証する。家電リサイクルにおける手続き的 知識は処分方法と料金の後払いに分けることができる。 適正廃棄の際には実質的に預り金からリサイクル料金が 差し引かれることから, 特に料金の後払いの認識は個人 のベネフィットの観点でも預り金への属性評価に影響す る可能性がある。そこで手続き的知識は, 引き渡し方法 についての知識 (方法知識) と料金の支払いについての 知識 (料金知識) に分けて質問する（図 1)。

\section{4. 分析手法と調查方法}

\section{1 分析手法}

本論では, 複数属性をもつ対象の評価が可能なコン ジョイント分析を用いて属性評価を推定し, 回答前に行 為同定を操作するメッセージを提示した群と何も提示し なかった群との間でパラメータ推定量を比較することで 説得的コミュニケーションの効果を推定する。コンジョ イント分析の代表的な質問形式としては, 評定型, 選択 型等がある ${ }^{23,24)}$ 。この内の選択型は複数の選択肢から一 つを選択させる形式であり, 家電の購買行動との整合性 が高いため, 本論ではこの形式を採用する。具体的な メッセージ等を含む調査票の設計については 4.3 に示す。 消費者の多属性意思決定の方略には複数の類型がある ことが知られている（補償型や辞書編纂型等の非補償 型) ${ }^{24)}$ 。非補償型, すなわち属性間で補償が利かない意
思決定方略は，属性数に対して認知的な資源が十分に利 用できない場合等, 意思決定における認知的な負荷の節 約が必要な場合に支配的になることが知られている ${ }^{24)} 。$ 評価介入モデルで仮定する属性変数の数は 3 つであり, 認知的な負荷は低いと考えられるため線形効用モデル (補償型) を採用する。

\section{1 .1 属性評価の推定}

図 1 に示したように属性変数を説明変数とし, 総効用 に依存する購入意図を被説明変数とする。選択型コン ジョイント分析ではランダム効用モデルが用いられる ${ }^{25)}$ ランダム効用モデルは, 効用は決定的な項 $V$ と確率的 な項 $\varepsilon$ からる。回答者 $n$ が選択肢 $i$ を選択するときの 全体効用 $U_{n i}$ を次式のようなランダム効用モデルを用い て表す25)。

$$
U_{n i}=V_{n i}+\varepsilon_{n i}
$$

$V_{n i}$ は効用関数のうち観察可能な部分であり， $\varepsilon_{n i}$ は観 察不可能な誤差項である。この時, 回答者 $n$ が選択肢 $i$ を選択する確率は, 選択肢 $i$ の効用が他の選択肢 $j$ の効 用よりも大きくなる確率と等しい。よって, 選択確率 $P_{n i}$ は式(2) で表される。

$$
\begin{aligned}
P_{n i} & =\operatorname{Pr}\left(U_{n i}>U_{n j}, \forall j \neq i\right) \\
& =\operatorname{Pr}\left(V_{n i}-V_{n j}>\varepsilon_{n j}-\varepsilon_{n i}, \forall j \neq i\right)
\end{aligned}
$$

誤差項が第一種極值分布に従うと仮定できるとき，誤 差項の差はロジスティック分布に従い, $P_{n i}$ は, 式(3) で表される ${ }^{26) 。}$

$$
P_{n i}=\frac{\mathrm{e}^{V_{n i}}}{\sum_{j} \mathrm{e}^{V_{n j}}}
$$

観測可能な項 $V$ について式 (4) の線形効用関数を仮 定し, 観測された属性変数xから最尤法を用いてパラ

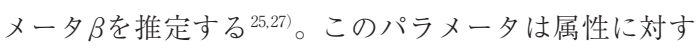
る評価（属性評価）と解釈される。

$$
V=\beta_{1} x_{1}+\beta_{2} x_{2}+\beta_{3} x_{3}
$$

ただし属性 $1 ， 2 ， 3$, はそれぞれ再生材使用率, 預り 金, 周囲の支持率を表す。 $\beta_{2}$ が負になることは預り金の 支払いが消費者に負担感（負の効用）をもたらすことを 意味する。

\section{1 .2 群間での属性評価の差の推定}

異なる群間でのパラメータ推定量の差について検定を 行い, メッセージが属性評価に与える影響を検証する。 まず各群の効用関数に差があるかどうかを調べるため尤 度比検定を行う。ある 2 群 $(A$ と $B)$ についての尤度 比検定では, 次の帰無仮説 


$$
\mathrm{H}_{0}: \beta^{A}=\beta^{B}
$$

のもとで，式(5) によって計算される統計量 $\lambda$ が属性 変数の数を自由度とするカイ 2 乗分布に従うことを用い て検定を行う ${ }^{28)}$ 。

$$
\lambda=-2\left\{L^{A B}-\left(L^{A}+L^{B}\right)\right\}
$$

ここで $L^{A B}$ は $A$ 群と $B$ 群を合わせた標本についての 対数尤度, $L^{A}$ は $A$ 群についての対数尤度, $L^{B}$ は $B$ 群に ついての対数尤度である。2つの効用関数に有意な差が ある場合，Wald 検定によって差を生じさせた推定パラ メー夕を明らかにすることができる。ある属性 $x_{k}$ の推定 パラメー夕 $\hat{\beta}_{k}$ の差について, 統計量 $t$ は式(6) から求め られる ${ }^{28)}$ 。

$$
t=\frac{\hat{\beta}_{k}^{A}-\hat{\beta}_{k}^{B}}{\sqrt{\operatorname{var}\left(\hat{\beta}_{k}^{A}\right)+\operatorname{var}\left(\hat{\beta}_{k}^{B}\right)}}
$$

ここで $A$ 群と $B$ 群それぞれのパラメータ推定量を $\widehat{\beta}_{k}^{A}$, $\hat{\beta}_{k}^{B}$ とする。

\section{2 預り金の水準}

預り金の規模は適正廃棄の経済的インセンティブの観 点から設定する。消費者の視点で経済的インセンティブ の実効性を確保するためには退蔵や市中回収業者等の実 質的に処理費用がかからない選択肢が存在することを考 慮する必要がある。そこで払い戻し金がリサイクル料金 と収集運搬費用の合計を上回るような水準の預り金を設 定する。この収集運搬費用は品目や収集運搬をする業者 によるが，2006 年の調査によれば家電量販店で買い換 える場合は 500 円から 1,500 円，買い換えを伴わない場 合では 500 円から 4,500 円になると見積もられる ${ }^{29)} 。$

家電リサイクル制度の開始以来, 消費税率の引き上げ を除けばリサイクル料金は減少傾向にあるため, 本論で は大幅な増加はないと仮定する。また戸別収集運搬費用 についても大幅な増加はないと仮定する。すべての品目 について質問票を回答することは回答者の負担が大きく， 回答の信頼性が低下するおそれがあることから, 本論で は対象品目のうちテレビについてのみ（具体的には 5 . で述べるとおり 40 型のテレビ）を対象とする。この品 目の場合,リサイクル料金は 3,000 円程度（原稿執筆時 点では 16 型以上の薄型テレビで 2,916 円) である。 よってこの品目の場合, 上述の収集運搬費用とリサイク ル料金の合計より，払い戻し金は 3,500 円から 7,500 円 程度に設定する必要があると見積もられる。

本論では回答者にとってのわかりやすさを重視し、リ サイクル料金と戸別収集運搬費用の合計は管理料金より
も十分に大きいと想定されることも踏まえて, 調査では 管理料金については省略し, 預り金と払い戻し金は同額 とした。

\section{3 質問票の設計とサンプル}

製品の性能, 製品価格の属性についての認識を一定に するため, 回答者には回答前に前提条件（40 型フルハ イビジョン, 税込 65,000 円, 製品寿命 7 年) をテレビ のイラストとともに提示した。回答者には預り金と払い 戻し金が同額となることを告知した。

プロファイル作成に用いた属性変数の水準は表 1 のと おりである。再生材使用率については, すべての部品・ 部材に再生材を使用することは現実的でなく，質問にリ アリティをもたせるため, 提示する属性水準の上限は低 めに設定した。預り金の水準については 4.2 で見積もら れた預り金の規模をもとに設定した。製品の重量やサイ ズの観点から，実際のデポジット制度では製品によって 異なる預り金を設定することになると考えられる。同種 の製品について預り金を細分化することは実務的に非効 率的になる可能性もあるが, 本論では預り金の徴収に対 する評価を推定することを目的に，預り金を製品属性と して扱った。周囲の支持率は直観的なわかりやすさを考 慮し表現と水準を設定した。

属性水準の組み合せは 48 とおりあるが, 回答者の負 担の軽減と測定の効率性を高めるため SPSS Conjoint 22 の ORTHOPLAN を用いて, 直交性から実際に測定に 用いる 18 個のプロファイルを作成した。これらのプロ ファイルから全体効用のバランスを考慮して 6 つのチョ イスセットを作成し，回答者にそれぞれのチョイスセッ トで最も好ましいプロファイルを選択してもらった。

回答の収集は 2014 年の 12 月にインターネット調査会 社（Macromill）に依頼した。男女比と地域分布につい て国勢調査の分布に合わせた割り付けを行い, 回答を収 集した。有効回答者数は 840 人であった。回答者は無作 為に何も情報を提示しない統制群 $(n=416)$ とメッ セージを提示する群に割り振り, さらに後者を無作為に 高次同定群 $(n=212)$ と低次同定群 $(n=212)$ に割り 振った。高次同定群と低次同定群には回答前にそれぞれ

表 1 属性変数の水準

\begin{tabular}{lcccc}
\hline \multicolumn{1}{c}{ 属 性 } & 水準 1 & 水準 2 & 水準 3 & 水準 4 \\
\hline 再生材使用率 & $10 \%$ & $30 \%$ & $50 \%$ & $70 \%$ \\
預り金 & 0 円 & 3,000 円 & 5,000 円 & 10,000 円 \\
周囲の支持率 & $0 \% * 1$ & $50 \% * 2$ & $100 \% * 3$ & - \\
\hline
\end{tabular}

*1アンケートでは「誰もこの選択肢に好意的でない」と表現した *2アンケートでは「半数がこの選択肢に好意的である」と表現した *3アンケートでは「全員がこの選択肢に好意的である」と表現した 
表 2 行為同定を操作するために提示したメッセージ

高次同定群 “不用品回収業者等に引き渡された家電の多くは 海外へ輸出され，不適切に処理されています。 その結果, 土壤污染等の深刻な環境污染や健康 被害を引き起こす原因となっています。また, 家電製品の多くは有価金属を含んでおり，使用 済み家電を輸出することは, 資源にそしい我が 国の国内資源循環の妨げにもなっています。”

低次同定群 “家電リサイクル法は, 家電メーカーに回収さ れた家電製品を引き取ってリサイクルすること を義務付けています。2001 年に施行されたこの 法律により，2005 年には社会全体で540 億円の 改善効果あったと見積もられています。また 2013 年度には, メーカーに回収された液晶テレ ビの内， $89 \%$ がリサイクルされました。”

に対応するメッセージを提示した。メッセージの内容は それぞれ, 高次同定では背景問題について, 低次同定で は実績や規範性等，制度の現状についての具体的な情報 である（表 2)。提示したメッセージの内容は 2014 年時 点で利用可能であった公開資料の内容をもとに設計した。 また実際のポスター掲示等の広報活動では内容を簡潔に まとめることも求められる。そこで設計にあたっては実 際の広報の実態に近いメッセージを設計することを目的 に細かい定義や前提条件等は省略した。加えて制御群と 情報提示を行った群の間でのパラメータ推定量の差を明 確にするため, 家電リサイクル制度にかかわる説明は上 述の情報提示のみとし, 想定するデポジット制度の政策 的枠組みについての説明は省略した。廃棄の知識の有無 は情報提示による影響を明確にするため, プロファイル 選択の後に質問した。

コンジョイント分析は行為同定についての 3 群と, こ れらの群を方法知識と料金知識の有無についてそれぞれ 分割した 12 群について行った（図 1)。

\section{5. 結果と考察}

行為同定についての 3 群すべてに抄いて， $\beta_{2}$ の推定量 は $0.01 \%$ 水準で有意であり, かつ符号はすべて負で あったことから，預り金の徴収により購入確率が減少す ることが確認された（表 3)。この結果を式(3) に代入 すると，具体的には 1,000 円の預り金の増加はすべての 群で $3 \%$ 前後の購入確率減少をもたらすと推定される。

\section{1 行為同定と属性評価}

高次同定群と低次同定群それぞれについて, 統制群と の間で尤度比検定 $(f=3)$ を行った。その結果, 高次同 定群と統制群の間 $(\lambda=8.976, p=0.030)$, 低次同定群と 統制群の間 $(\lambda=2.888, p=0.409)$ では, 前者のみ $5 \%$ 水 準で有意差がみられた。この結果は, 提示したメッセー
表 3 行為同定に関する 3 群についてのパラメー夕推定量

\begin{tabular}{lccc}
\hline \multicolumn{1}{c}{ 変 数 } & 高次同定群 & 低次同定群 & 統 制 群 \\
\hline 再生材使用率 & $0.308^{* * * *}$ & $0.168^{* * * *}$ & $0.184^{* * *}$ \\
$(20 \%$ あたり $)$ & $(8.89)$ & $(5.04)$ & $(12.14)$ \\
預り金 & $-0.127^{* * *}$ & $-0.144^{* * *}$ & $-0.123^{* * *}$ \\
$(1000$ 円あたり $)$ & $(-12.36)$ & $(-13.67)$ & $(12.14)$ \\
周囲の支持率 & $0.361^{* * *}$ & $0.333^{* * *}$ & $0.320^{* * *}$ \\
$(50 \%$ あたり & $(9.73)$ & $(8.89)$ & $(12.14)$ \\
\hline 対数尤度 & -1240.755 & -1249.384 & -2498.417 \\
AIC & 2487.509 & 2504.768 & 5002.834 \\
標本数 & 212 & 212 & 416 \\
\hline
\end{tabular}

注）（）は $Z$ 值。 ${ }^{* * *}$ は $0.1 \%$ 水準, ${ }^{* *}$ は $1 \%$ 水準, ${ }^{*} 5 \%$ 水準で 有意を意味する

ジによって家電リサイクルについての解棌が操作された ことを示す。アンケート調査では，しばしば回答者が質 問者にとって望ましいと思われる回答をするという傾向 (要求特性) が問題になるが, 本調査の回答者は少なく ともリサイクルや資源といったキーワードから望ましさ に基づいた判断をせず, 情報の内容について解釈を行っ たと考えられる。

尤度比検定で有意差のみられた高次同定群と統制群の 間で, 各パラメー夕推定量の差について $t$ 検定を行った。 $\beta_{1}$ (再生材使用率: $\left.t=2.961, p=0.005\right), \quad \beta_{2}$ (預り金 : $t=$ $-0.318, p=0.379$ ), $\beta_{3}$ (周囲の支持率: $t=0.902, p=$ 0.265）のうち, 再生材使用率のみ $5 \%$ 水準で有意差が みられた。表 3 をみると高次同定群のほうが $\beta_{1}$ の推定量 が大きく，高次同定を促すことによって再生材使用率の 評価を高める方策が有効であることが示唆された。一方 で，低次同定群と統制群の間ではいずれの属性について もパラメータ推定量に大きな差はみられず，低次同定を 促すメッセージには行為同定を変えるような新しい情報 が含まれていなかったと考えられる。この結果から消費 者は家電リサイクルへの貢献を低次レベルで同定してい ることが示唆される。

\section{2 受け手の知識と属性評価}

次に受け手の知識がメッセージの受容と属性評価に与 える影響について検証する。まず行為同定の 3 群につい て, 各知識の有無の間で尤度比検定 $(f=3)$ を行った。 その結果メッセージを提示した 2 群については, 高次同 定群における方法知識の有無 $(\lambda=8.297, p=0.040)$, 高 次同定群における料金知識の有無 $(\lambda=12.454, p=0.006)$, 低次同定群における料金知識の有無 $(\lambda=25.356, p=$ 0.000）について $5 \%$ 水準で有意差がみられ, 低次同定 群に扔ける方法知識の有無 $(\lambda=6.438, p=0.092)$ のみ $5 \%$ 水準で有意差はみられなかった。統制群に扔ける手続き 的知識の尤度比検定では, 料金知識の有無 $(\lambda=5.942$, 
表 4 引き渡し方法についての知識の有無によるパラメータ推定量の違い

\begin{tabular}{lcccccc}
\hline & \multicolumn{2}{c}{ 高次同定群 } & \multicolumn{2}{c}{ 低次同定群 } & \multicolumn{2}{c}{ 統 制 群 } \\
\cline { 2 - 6 } & 方法知識あり & 方法知識なし & 方法知識あり & 方法知識なし & 方法知識あり & 方法知識なし \\
\hline \multirow{2}{*}{$\beta_{1}$ : 再生材使用率 } & $0.377^{* * *}$ & $0.277^{* * *}$ & $0.165^{* * *}$ & $0.125^{* * *}$ & $0.237^{* * *}$ & $0.157^{* * * *}$ \\
\multirow{3}{*}{$\beta_{2}$ : 預り金 } & $(5.80)$ & $(6.58)$ & $(3.08)$ & $(2.74)$ & $(5.75)$ & $(5.14)$ \\
& $-0.136^{* * *}$ & $-0.120^{* * *}$ & $-0.111^{* * *}$ & $-0.164^{* * *}$ & $-0.136^{* * *}$ & $-0.112^{* * *}$ \\
$\beta_{3}$ : 周囲の支持率 & $(-7.32)$ & $(-9.62)$ & $(-7.04)$ & $(-11.62)$ & $(-11.15)$ & $(-12.42)$ \\
& $0.232^{* * *}$ & $0.401^{* * *}$ & $0.303^{* * *}$ & $0.337^{* * *}$ & $0.313^{* * *}$ & $0.311^{* * * *}$ \\
対数尤度 & $(3.57)$ & $(9.03)$ & $(5.28)$ & $(6.91)$ & $(7.28)$ & $(9.52)$ \\
AIC & -383.463 & -856.023 & -516.595 & -734.162 & -907.655 & -1590.638 \\
標本数 & 772.9252 & 1718.045 & 1039.190 & 1474.324 & 1821.309 & 3187.276 \\
\hline
\end{tabular}

注）（）は $Z$ 值。 ${ }^{* * * *}$ は $0.1 \%$ 水準, ${ }^{* *}$ は $1 \%$ 水準, ${ }^{*} 5 \%$ 水準で有意を意味する

表 5 料金の支払いについての知識の有無によるパラメータ推定量の違い

\begin{tabular}{lcccccc}
\hline & \multicolumn{2}{c}{ 高次同定群 } & \multicolumn{2}{c}{ 低次同定群 } & \multicolumn{2}{c}{ 統 制 群 } \\
\cline { 2 - 6 } & 料金知識あり & 料金知識なし & 料金知識あり & 料金知識なし & 料金知識あり & 料金知識なし \\
\hline \multirow{2}{*}{$\beta_{1}$ : 再生材使用率 } & $0.403^{* * *}$ & $0.237^{* * *}$ & $0.180^{* * *}$ & 0.097 & $0.254^{* * *}$ & $0.144^{* * * *}$ \\
& $(7.32)$ & $(5.1)$ & $(3.78)$ & $(1.89)$ & $(6.97)$ & $(3.98)$ \\
$\beta_{2}$ : 預り金 & $-0.146^{* * *}$ & $-0.109^{* * *}$ & $-0.094^{* * *}$ & $-0.198^{* * *}$ & $-0.117^{* * *}$ & $-0.135^{* * *}$ \\
& $(-9.21)$ & $(-7.92)$ & $(-6.74)$ & $(-12.07)$ & $(-10.97)$ & $(-12.34)$ \\
$\beta_{3}$ : 周囲の支持率 & $0.291^{* * *}$ & $0.398^{* * * *}$ & $0.283^{* * *}$ & $0.377^{* * *}$ & $0.316^{* * *}$ & $0.312^{* * * *}$ \\
& $(5.33)$ & $(8.03)$ & $(5.52)$ & $(6.92)$ & $(8.27)$ & $(8.04)$ \\
\hline 対数尤度 & -547.429 & -689.978 & -685.534 & -600.094 & -1141.413 & -1138.034 \\
AIC & 1100.859 & 1385.955 & 1288.409 & 1206.187 & 2288.826 & 2282.067 \\
標本数 & 96 & 116 & 104 & 108 & 191 & 225 \\
\hline
\end{tabular}

注）（）は $Z$ 值。 ${ }^{* * *}$ は $0.1 \%$ 水準， ${ }^{* *}$ は $1 \%$ 水準, ${ }^{*} 5 \%$ 水準で有意を意味する

$p=0.114)$, 方法知識の有無 $(\lambda=5.091, p=0.165)$ とも に 5 \% 水準で有意差はみられず, 受け手の知識自体は 属性評価に影響しなかった。

行為同定についての 3 群を方法知識と料金知識の有無 でそれぞれ分割した 12 群についてパラメータを推定し た結果，低次同定群メ料金知識なし群を除いて，すべて のパラメータ推定量が $5 \%$ 水準で有意であった（表 4 , 表 5)。続いて尤度比検定で有意差がみられた群間につ いて, 知識の有無による各パラメー夕推定量の差につい て $t$ 検定を行った。

低次同定群に求ける料金知識の有無による比較では $\beta_{2}$ の推定量にのみ有意な差がみられ（表 6), 低次同定群 では料金知識をもつ群のほうが $\beta_{2}$ の推定量が大きく(絶 対值が小さく), 預り金徵収の負担感が相対的に小さい という結果が得られた（表 5)。また低次同定群 $\times$ 方法 知識については, 尤度比検定では $5 \%$ 水準で有意差は みられなかったものの, p 值は 0.092 と低く, $\beta_{2}$ の推定 量の差についても $5 \%$ 水準で有意差がみられた $(t=2.503, p=0.018)$ 。一方で先に述べたように統制群 では料金知識の有無と属性評価の間に有意な差はみられ なかった。よってリサイクル料金に関する知識は預り金 の支払いに対する負担感よりも，家電リサイクルの行為
表 6 尤度比検定で有意差のみられた群についてのパラ メータ推定量の差（各セルの值は知識を有する群 の推定量から知識を有さない群の推定量を引いた 值を表す)

\begin{tabular}{lccc}
\hline & 高次同定群 $\times$ & 低次同定群 $\times$ & 高次同定群 $\times$ \\
& 料金知識の有無 & 料金知識の有無 & 方法知識の有無 \\
\hline \multirow{2}{*}{$\beta_{1}$ : 再生材使用率 } & $0.166^{*}$ & 0.083 & 0.100 \\
& $(2.30)$ & $(1.19)$ & $(1.29)$ \\
\multirow{3}{*}{$\beta_{2}$ : 預り金 } & -0.037 & $0.104^{* * *}$ & -0.016 \\
\multirow{2}{*}{$\beta_{3}$ : 周囲の支持率 } & $(-1.77)$ & $(4.84)$ & $(-0.72)$ \\
& $(-1.45)$ & $(-1.26)$ & $(-2.15)$ \\
\hline
\end{tabular}

注）（）は $t$ 值。*** は $0.1 \%$ 水準, ${ }^{* *}$ は $1 \%$ 水準, ${ }^{*} 5 \%$ 水準で 有意を意味する

同定，すなわち消費者が家電リサイクルをどのような抽 象レベルの結果と関連づけるかに大きく関連することが 示唆される。

手続き的知識を有する消費者は過去に家電リサイクル 制度について何らかの接点（実際に制度にのっとって廃 棄した，広報を見たなど）をもったことがあることを意 味する。結果的にこの消費者グループは家電リサイクル の制度的側面, 特に適正廃棄の文脈を連想しやすく（す なわち心理的距離が近く), この行動を促進することを 目的としたデポジット制度の受容性が高いと考えられる。 
つまり預り金の支払いへの負担感を軽減する観点で, こ れらの結果は制度的な側面を強調するメッセージの提示 は手続き的知識を有する消費者に対してより効果的であ ることを示唆する。

また手続き的知識は高次同定のメッセージの受容にも 影響を与えることが見て取れる。高次同定群における料 金知識の有無では再生材使用率 $\left(\beta_{1}\right)$ について, 方法知 識の有無では周囲の支持率 $\left(\beta_{3}\right)$ について推定量に有意 な差がみられた（表 6)。より具体的には，料金知識を 有する群では再生材使用率への評価が高く（表 5), 方 法知識を有する群では周囲の支持率への評価が低かった (表 4)。パラメータ推定量の差についての $t$ 検定では 5 $\%$ 水準で有意でなかったが, 表 4, 5 をみると高次同定 群においてはいずれの知識についても知識を有する群に おいて $\beta_{1}$ が大きい，すなわち再生材使用率の評価が高く， また $\beta_{3}$ が小さい，すなわち周囲の支持率への評価が低い という傾向がみられた。手続き的知識が低次同定だけで なく高次同定を促すメッセージの受容にも関係すること が明らかとなった。これは評価介入モデルで想定した解 䣋レベルと心理的距離の関係からは説明できない結果で ある。そこで手続き的知識自体の認知的機能だけでなく， その知識を獲得する過程からの影響についても考えてみ る。

家電リサイクル制度の手続き的知識はごみの分別方法 と異なり, 日常生活の中で無意識に得ることは難しい。 手続き的知識の獲得には能動的な情報探索が必要であり, その動機は過去の使用済み製品の処分であった可能性が 高い。適正廃棄行動の経験と手続き的知識の有無の関係 については追加的な調査が必要であるが, 知識の獲得機 会を考慮すると, 手続き的知識を有する群ではその多く が適正廃棄行動をした経験を有すると考えられる。表 4 , 5 をみると高次同定群においては, 方法知識を有する群 よりも料金知識を有する群において再生材使用率に対す る評価が高いことが見て取れる。方法知識よりも能動的 な知識獲得の機会が限られると考えられることから, 料 金知識は適正廃棄行動の過程で獲得されたと考えられる。

うまく実行されている行為は自動的に実行されやすく なり, 自動的な実行の範囲内では行為の経験を深めてい くほど, 人はその行為を高次同定しやすくなることが知 られている ${ }^{17,20)}$ 。高次同定のメッセージの提示は過去の 適正廃较行動を高次レベルで再同定することを促し，リ サイクルによって社会的課題を解決するという行為目標 のもとで, 適正廃棄行動と再生材使用率の高い製品の選 択が一貫的な行動であるという認知を促したと推察され る。結果, 手続き的知識を有する回答者は態度の一貫性 を維持するため再生材により高い評価を与えたと推察さ
れる。

以上の議論の実務的な示唆は, 行為同定のメッセージ によって“購買”行動に介入する際に, “廃棄の”手続 き的知識はメッセージの有効性にかかわるファクターと なるということである。受け手の知識に合わせてメッ セージを設計し, 対応する製品属性を明示することで効 果的な説得的コミュニケーションが期待できる。

\section{3 評価介入による効用減少分の補償可能性}

最後に得られた属性評価が需要に与える影響の規模を 推察する。デポジット制度開始前の需要を一定とするこ とで, 預り金の支払いや評価介入による製品需要の変化 は製品の購入確率（式 3) の変化として捉えることがで きる ${ }^{23)}$ 。 4.2 では適正廃棄行動の経済的インセンティブ を付与するために必要な預り金を，買い替えを伴う場合 は4500 円，買い換えを伴わない場合は 7,500 円と設定 した。図 2,3 はこれらの水準を含む区間に注目したと き, 預り金の増加に対して徴収前の効用水準の維持に必 要な再生材使用率を表す。

低次同定群においては料金知識, 方法知識双方につい て, これらをもたない群においては, 再生材使用率の上 限值である 1 になってもこれらの図に示される区間にあ る預り金徵収による効用の減少分が完全に補償されない ことが明らかとなった。したがってこれらの群に対応す る曲線は図の領域には含まれない。低次同定群と統制群 の間では尤度比検定における有意差は認められなかった が，図 2，3において線が上方に来ることからわかるよ

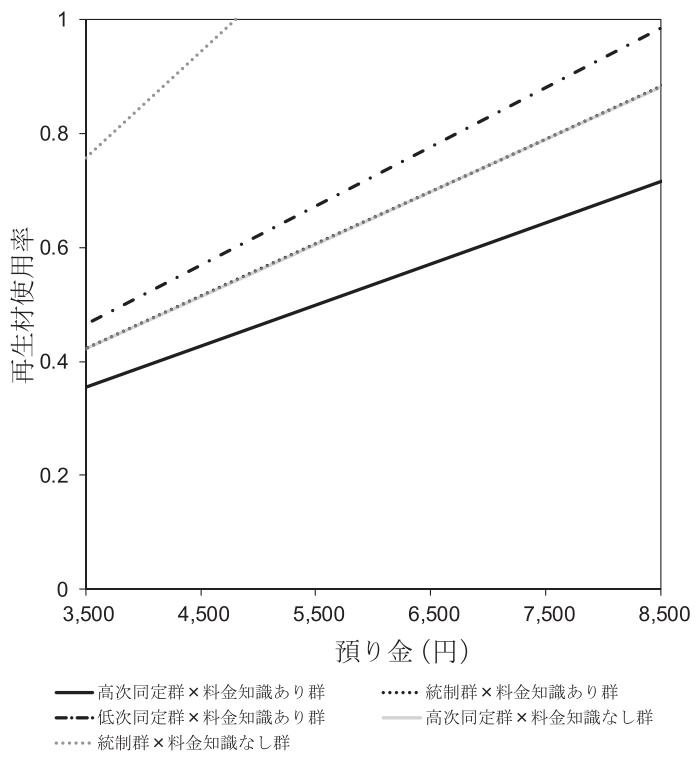

図 2 預り金徴収による効用低下を補償するために必要 な再生材使用率（料金知識の有無について） 


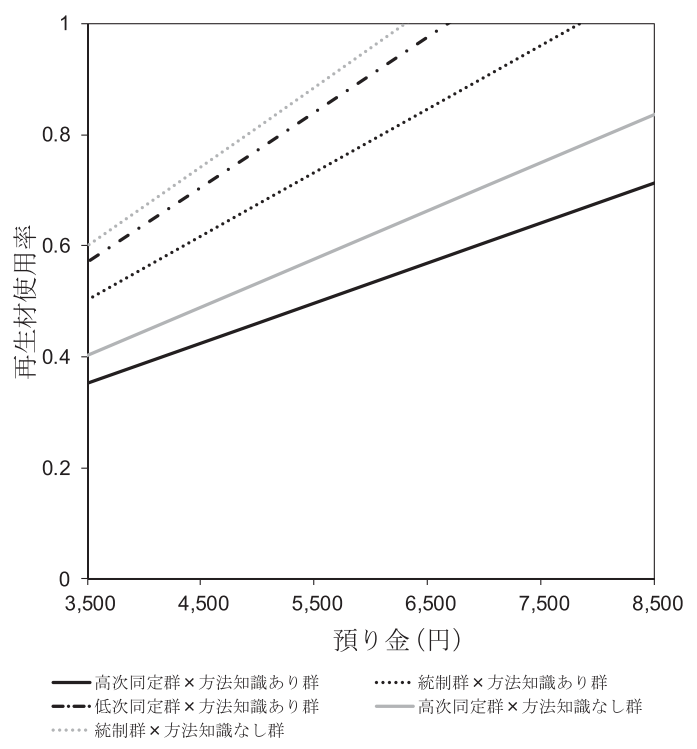

図 3 預り金徵収による効用低下を補償するために必要 な再生材使用率（方法知識の有無について）

うに, 低次同定群のほうが再生材使用率による補償の効 果は相対的に低かった。この理由として低次同定で提示 したメッセージでは回収された使用済み製品の大半がリ サイクルされていると告知したため, 低次同定群の回答 者はリサイクルされた製品は家電製品の製造に使われて いると捉え，再生材を使用した製品を自主的に選択する 必要性がないと判断した可能性が考えられる。低次同定 の促進以外の効果を排除するという意味において, 提示 したメッセージに改善の余地があるといえる。

高次同定群では情報提示により, 統制群よりも効用の 減少分を補償するために必要な再生材使用率の水準が低 く, 預り金を 7,500 円に設定しても手続き的知識の有無 にかかわらず効用の減少分の補償が可能であった。また 行為同定の各群において, 手続き的知識を有する群では 有さない群よりも補償のために必要な再生材使用率の水 準が低かった。再生材使用率と高次同定を適切に組み合 わせることで, デポジット制度は廃棄と購買の両面でリ サイクル行動促進に寄与することが期待できる。

一方で, 得られた結果からは現実的な課題も浮き彫り になる。図 2,3 は, 買い換えを想定し高次同定を促し た場合でも, 効用の減少分を完全に補償するためには現 状よりも大幅に再生材使用率を増やす必要があることを 示している。 4.2 で試算したように預り金は最も少ない 場合でも 3,500 円程度に設定する必要があり, 図 2,3 はこの支払いへの負担感を補償するために必要な再生材 使用率は $40 \%$ 程度であることを示している。しかし実 際には対象品目の再生材使用率の水準は $40 \%$ より
幅に低いと推測される ${ }^{30)}$ 。本論では再生材使用率と製品 価格が独立していることを仮定したが, 過度の再生材の 使用は製造コストの増加を招く可能性があり，また品質 的な制約も考えられる。これらの属性は個人のベネ フィットに関係することから, これらの属性も含めた評 価介入モデルの検討は今後の研究的課題である。

また本論では効用補償に必要な再生材使用率を具体的 に推定することではなく，あくまで消費者行動の観点で リサイクルを促進する方策を検討することを目的とした ため, メッセージの設計では内容の簡潔性を重視した。 提示されたメッセージ中の用語の解釈については特にコ ントロールされておらず, 回答者によっては政策立案的 な用法と一致しない解釈をした可能性も考えられる。た とえば回収された製品のリサイクル率の定義や提示され た再生材使用率の技術的含意等について, 提示内容の受 け止め方が回答者のバイアスに影響された可能性も考え られる。したがって 40 \%という再生材使用率がもたら す効用は, 政策についての適切な理解によって得られた 結果ではないことに留意する必要がある。適切な政策理 解を促進するメッセージの設計は今後の研究的課題であ る。

\section{6.おわりに}

本論では情報提示による支払いに対する負担感への介 入の有効性について分析することを目的とし, 行為の目 標を操作し，製品属性と組み合わせることで，デポジッ 卜制度の導入による負担感掞よびそれによる製品需要の 低下を軽減する方策について検討した。これまで公的な リサイクル制度の下での行為同定が属性評価に与える影 響についての報告例はなく，この点で本論は新しい。

消費者調査から預り金の徴収はテレビの購入の全体効 用を減少させることが確認され, 行為同定に焦点を当て た情報と製品属性の提示を適切に組み合わせることに よって負担感の軽減が可能であることが示された。この 結果の最も重要な実務的示唆は, リサイクル制度の理解 の促進と一言にいっても, 説得的コミュニケーションの 効果がメッセージの内容に大きく左右されることである。

得られた結果からリサイクル行動を高次に同定するこ とを促す，すなわち適正廃棄の促進を強調するよりも家 電リサイクルの社会的意義について強調することで, 効 果的な説得的コミュニケーションが得られること, また 過去の適正廃棄行動が説得的コミュニケーションの受容 性に影響を与える可能性が示唆された。製品の再生材使 用率が十分に高い場合には, 適正廃棄行動の経済的イン センティブの付与と製品需要の維持は両立しうることが 
明らかとなった。経済的インセンティブを確保するため には最低でも 3,500 円程度の預り金徵収が必要であると 考えられる。この預り金徴収によって減少する効用を完 全に補償するために必要な再生材使用率の水準はテレビ 等の家電製品に拈ける現状の水準よりも大幅に高いこと も明らかになり，現実的な難しさも浮き彫りとなった。 本論で考慮した製品属性は再生材使用率, 預り金, 製品 に対する周囲の支持率であったが，これ以外の属性につ いては今後の検討課題である。

また支払いによる負担感の観点では,リサイクル料金 の徵収も預り金と同様に製品需要に影響を及ぼすと考え られる。したがって本論で検討した行為同定と製品属性 の組み合わせによる購買行動の介入は, 前払い方式の導 入による製品需要の低下への対策の検討においても示唆 的であると考えられる。ただりサイクル料金は預り金 と制度上の目的が異なり，消費者がリサイクル料金の支 払いをどのように行為同定するかについては別途調査が 必要である。

\section{[謝 辞 $]$}

調査の設計にあたり，アンケート設計にご協力い ただいた高橋裕也氏に感謝いたします。

\section{参考文献}

1）産業構造審議会 産業技術環境分科会 廃棄物・リサイ クル, 小委員会 電気・電子機器リサイクルワーキング グループ, 中央環境審議会 循環型社会部会, 家電リサ イクル制度評価検討小委員会＆合同会合：家電リサイ クル制度の施行状況の評価・検討に関する報告書 (2014)

2 ）環境省：いらなくなった家電製品は正しくリユース・ リサイクル!

https: //www.env.go.jp/recycle/kaden/tv-recycle.ht $\mathrm{ml}$ (閲覧日 2018 年 11 月 17 日)

3) みずほ情報総研 (株): 平成 27 年度 使用済家電 4 品目の 経過年数等調査 (2016)

http : //www.aeha.or.jp/sitei/pdf/27_keikanensuu.pdf (閲覧日 2018 年 6 月 12 日)

4) 経済産業省：家電リサイクル法 資料集 http : //www.meti.go.jp/policy/it_policy/kaden_recyc le/shiryousyu/shiryou.html

（閲覧日 2018 年 11 月 17 日）

5 ) Z. Ma and Y. Dai: An Exploration of the DepositRefund System for WEEE Recycling in China, 日本情報 経営学会誌, 第 33 巻, pp. 164-171(2012)

6 ）沼田大輔：デポジット制度は製品需要に影響を与える か, 環境科学会誌, 第 19 巻, pp. 371-384 (2006)

7 ) 田崎智宏, 寺園淳, 森口祐一: 家電リサイクル法の効 力測定, 環境科学会誌, 第 8 巻, pp. 229-242 (2005)
8) 陎 三菱総合研究所 : 平成 29 年度我が国におけるデー 夕駆動型社会に係る基盤整備（家電リサイクル法に係 る回収促進等に関する調查) 報告書（2018）

9 ）産業構造審議会 廃裹物・リサイクル小委員会, 電気 · 電子機器ワーキンググループ, 中央環境審議会 廃棄 物・リサイクル部会, 家電リサイクル制度評価検討小 委員会＆合同会合 : 家電リサイクル制度の施行状況の 評価・検討に関する報告書（2008）

http : //www.meti.go.jp/meti_lib/report/H29FY/0008 76.pdf（閲覧日 2018 年 6 月 12 日）

10）産業構造審議会 廃棄物処理 ·再資源化部会 企画小委 員会 電気・電子機器リサイクル分科会 : 電気 $\cdot$ 電子 機器のリサイクルの促進にむけて〜産業構造審議会 廃 棄物処理 ·再資源化部会 企画小委員会, 電気. 電子機 器リサイクル分科会報告書〜 (1997)

11）貫真英, 遠山智久：企業数と需要変動, および利潤の 関係—ーリサクル制度を念頭に一, 工学院大学 研究論叢, 第 46 巻, pp. 7-16 (2008)

12）産業構造審議会 産業技術分科会 廃裹物・リサイクル 小委員会 自動車リサイクル WG 中央環境審議会 循環 型社会部会 自動車リサイクル専門委員会 : 指定法人の 費用について（2015）

13）自動車リサイクル促進センター：資金管理料金・輸出 取戻し手数料 | 自動車リサイクルとは

https: //www.jarc.or.jp/automobile/designated-corp/ fund/fund/(閲覽日 2018 年 6 月 12 日)

14）(禈 日本電機工業会：2018 年度電気機器の見通し 資料 https : //www.jema-net.or.jp/Japanese/data/mitoshi/ pdf/2018mi_data.pdf（閲覽日 2018 年 11 月 17 日）

15）(䃾電子情報技術産業協会：民生用電子機器国内出荷統 計

https : //www.jeita.or.jp/japanese/stat/shipment/ (閲覧日 2018 年 11 月 17 日)

16）(神 日本自動車工業会：主要国の四輪車販売台数 http : //www.jama.or.jp/world/world/world_1t2.html (閲覽日 2018 年 11 月 17 日)

17) R. R. Vallacher and D. M. Wegner: What Do People Think They're Doing? Action Identification and Human Behavior, Psychological Review, Vol.94, pp.3-15 (1987)

18) S. T. Fiske and S. E. Taylor: Social Cognition: From Brains to Culture, 2nd Edition, Sage Publications (2013)

19）外川拓，八島明朗：解釈レベル理論を用いた消費者行 動研究の系譜と課題, 消費者行動研究 第 20 巻, pp. 65 -94 (2014)

20）八木田克英, 西尾チヅル：リデュース行動における情 報提供とエコプロダクト使用経験の効果, 広告科学, 第 511 巻, pp. 50-65 (2009)

21) N. Liberman, Y. Trope and E. Stephan : Psychological Distance, Social Psychology: Handbook of Basic Principles, 2nd Edition, The Guilford Press, pp. 353-383 (2007)

22）樋口収, 桑山恵: 空間的距離感が説得メッセージの 
受容に及ぼす影響, 社会心理学研究, 第 26 巻, pp. 178187 (2011)

23）合崎英男, 西村和志 : デー夕解析環境 Rによる選択型 コンジョイント分析入門, 農村工学研究所技報, 第 206 巻, pp. 151-173 (2007)

24) J. W. Payne, J. R. Bettman and E. J. Johnson: The Adaptive Decision Maker, Cambridge University Press (1993)

25) W. Adamowicz, J. Louviere and M. Williams: Combining Revealed and Stated Preference Methods for Valuing Environmental Amenities, J. Environ. Econ. Manage., Vol. 26, pp. 271-292 (1994)

26) D. McFadden: Conditional Logit Analysis of Qualitative Choice Behavior, Front. Econom., Academic Press, pp. 105-142 (1974)
27）栗山浩一, 石井 寞：リサイクル商品の環境価值と市場 競争力——コンジョイント分析による評価——, 環 境科学会誌, 第 12 巻, 第 1 号, pp. 17-26 (1999)

28) M. E. Ben-Akiva and S. R. Lerman: Discrete Choice Analysis: Theory and Application to Travel Demand, MIT Press (1985)

29）産業構造審議会 環境部会 廃棄物・リサイクル小委員 会 電気・電子機器リサイクルワーキンググループ中 央環境審議会 廃棄物・リサイクル部会家電リサイクル 制度評価検討小委員会: 家電リサイクル法の収集・運 搬料金に関する実態調査結果（2006）

30）家電. Watch. : パナソニック, リサイクル素材を使っ た生活家電シリーズ「資源循環商品」

https : //kaden. watch.impress. co.jp/docs/news/49860 $1 . h t m l （$ 閲覽日 2018 年 6 月 12 日）

\title{
How Consumer Knowledge Influences Evaluation of Product Attributes under a Deposit-refund Based Recycling Scheme :
}

A Case Study Based on TVs

\author{
Akiyuki Masuda*, Gaito Matsumoto* and Shinsuke Murakami* \\ * Department of Systems Innovation, Graduate School of Engineering, The University of Tokyo \\ $\uparrow$ Correspondence should be addressed to Shinsuke Murakami : \\ Department of Systems Innovation, Graduate School of Engineering, The University of Tokyo \\ (7-3-1 Hongo, Bunkyo-ku, Tokyo 113-8656 Japan)
}

\begin{abstract}
The promotion of formal behaviors for the disposal of home appliances has its limits when it comes to how much consumers can actually be positively influenced. In fact, change in behavior may greatly depend on improved consumer understanding of recycling systems. For example, although the Home Appliance Recycling Law came into effect back in 2001, rates for End-of-Life products covered under this law show room for much more improvement. One possible alternative is to introduce a deposit-refund system into the recycling system. This may, however, give rise to concerns that product demand could decrease due to the mandatory deposit payment. This paper analyses the relationship between provision of information regarding recycling systems and consumer perceptions concerning the burden of bearing costs for recycling. Using home appliance recycling (namely TVs) as an example, the paper begins by outlining a deposit-refund system in the current recycling scheme and introduces a design for a model of intervention to evaluate how consumers comprehend recycling-related product attributes based on action identification theory. The authors use a conjoint analysis to estimate impacts on the perception of the burden, and verify the effectiveness of the model for TV sets. Our results suggest that payment of a deposit is seen as a burden to consumers, and manipulating action identification of the purchase is suggested as an effective means of alleviating this perception.
\end{abstract}

Keywords : recycling, deposit-refund system, purchasing behavior, conjoint analysis 